http://jmscr.igmpublication.org/home/

ISSN (e)-2347-176x ISSN (p) 2455-0450

crossref DOI: https://dx.doi.org/10.18535/jmscr/v7i11.51

Journal Of Medical Science And Clinical Research

\title{
Estimation of serum lipase as a predicator of acute Pancreatitis
}

\author{
Authors \\ Dr Pankaj Bhushan ${ }^{1}$, Dr Usha Kumari ${ }^{2 *}$ \\ ${ }^{1}$ Assist. Professor, Deptt. of Biochemistry, ANMMCH , Gaya \\ ${ }^{2}$ Associate Professor, Deptt of Biochemistry, VIMS, Pawapuri (Nalanda) \\ *Corresponding Author \\ Dr Usha Kumari
}

\begin{abstract}
Estimation of serum lipase in case of pancreatitis is very important to reach the diagnosis of disease \& its prognosis. It is established fact that test for serum lipase is specific for diagnosis of acute \& chronic pancreatitis. Once diagnosis is established, treatment of pancreatitis started. Now serial estimation of serum lipase daily will provide information retarding prognosis of disease also. For example during recovery phase estimation of serum lipase daily will guide to the prognosis of disease. During this phase the serum lipase level goes to the base line. The aim and objective of this work is to predict the disease acute pancreatitis by estimation of serum lipase.
\end{abstract}

\section{Introduction}

Pancreatitis is a disease characterized by acute inflammation of pancreas with serve pain abdomen, nausea, vomiting \& shallow respiration .There is pain on deep breathing. Physical finding on palpation is tenderness in epigastrium, when epigastrium is firmly pressed.

Pancreas is one of the important organs in human body system. It is transversely oriented retroperitoneal organ extending from a "c" loop of the duodenum to the hilum of the spleen. Pancreas has two important functions.

1. Endocrine Function- Synthesis of Glucagon, insulin \& Gastrin

2. Exocrine Function- Synthesis of pancreatic amylase and lipase.

Normal serum amylase is 0-80 U/L and lipase is < 60U/L. In case of pancreatitis this level in being increased by many fold. In our study the secretion of exocrine gland of pancreas enters in duodenum through opening of pancreatic duct at ampulla of Vater. Therefore in case of perforation of duodenum, also there is chance of increased in level of lipase.

Biochemical finding correlated with acute pancreatitis are increased fasting blood glucose, increased serum amylase, decreased serum calcium, increased LHD. A contrast enhanced computed tomography (CECT) scan of abdomen in an important imaging test for acute pancreatitis.

\section{Review of Literature}

A CT severity index can be calculated according to Balthazar, et. al. (API Medicine Pg-1083, editin-10). In acute pancreatitis, a raise in serum amylase activity occurs within 5-8 hours of symptom onset; activities return to normal by the third or fourth day. A four to six fold elevation in 
amylase activity above the upper reference limit is usual, with maximum concentration attained in 12-72 hours. The magnitude of elevation of serum enzyme activity is not related to the severity of pancreatic involvement; however greater the rise, the greater the probability of acute pancreatitis. After an attack of acute pancreatitis, serum lipase activity increases within 4-8 hours, peak at about 24 hours, and decreases within 8-14 days ${ }^{(2)}$.

Some studies mentioned sensitivity for serum amylase was $63.6 \%$ and for the serum lipase it was $99.5 \%$, whereas, specificity for serum amylase $99.4 \%$ and for lipase $99.2 \%{ }^{(3)}$.

Many studies have been done in the past show that serum lipase is better marker than serum amylase for the diagnosis acute pancreatitis ${ }^{(4,5)}$ Although lipase is considered to be specific for acute pancreatitis, nonspecific elevation of lipase have been reported in almost as many disorders as amylase, thus decreasing its specificity ${ }^{(6)}$.

The current British society Gastroenterology guidelines (2005) for the management of acute pancreatitis has also agreed that estimation of lipase is better tool for diagnosis of acute pancreatitis ${ }^{(7)}$.

Before selection of the patient subjected for study, we should think for all the findings.

\section{Aims \& Objective}

Aim of this work was to predict the diagnosis of acute pancreatitis by estimation of serum lipase \& to know the prognosis of disease by serial estimation of serum lipase daily as soon as treatment has been subsituated.

\section{Material \& Method}

Adult (Male \& Female) patient of 20-60 years were suffering from acute pancreatitis were selected from OPD of general surgery \& OPD of Medicine at JLNMC \& H Bhagalpur. Patient was selected on the basis of clinical sign \& symptom of acute pancreatitis like serve pain abdomen\& epigastric discomfort. There is shallow respiration, fever, nausea \& Vomiting.

Biochemical analysis of blood for glucose calcium, sodium, potassium, bicarbonate, LDH, serum amylase \& serum lipase also done. Radiological diagnosis of acute pancreatitis by $\mathrm{X}$ ray abdomen in erect posture (air under diaphragm) USG abdomen (for G.B.Stone) CECT abdomen for severity score.

\section{Methodology}

Venous blood sample was drown in sterile disposal $5 \mathrm{ml}$ syringe from selected 50 patient of case (disease). Then blood were dropped in plain vial levelled with name, age, gender of the patient. By centrifugation method serum was obtained \& levelled accordingly.

Determination of serum amylase and lipase was done by semiautoanalyzar. This is kinetic colorimetric procedure. Patients were subjected for testing of serum amylase and lipase. After that full course of treatment of pancreatitis was given. Again serial estimation of serum lipase was done to know the prognosis of disease.

\section{Observation and Result}

Out of 50 sample size of diseased person maximum serum lipase value was 688U/L and minimum was 110 U/L. During the study period, a total of 50 patients were assessed with proven diagnosis of acute pancreatitis by radio imaging irrespective of etiology. However, out of 50 patients, 41 patients had both amylase and lipase raised, remaining 9 patients had amylase normal but lipase raised (Table 1). Amylase was raised up to 7 times of its upper limit of normal range (Fig.1)and lipase was raised up to ten times of its upper level of normal range (Fig.2). Sensitivity of lipase is $100 \%$.

Table-1 Levels of amylase and lipase

\begin{tabular}{|l|c|c|c|}
\hline $\begin{array}{l}\text { Acute Pancreatitis } \\
(\mathrm{n}=50)\end{array}$ & $\begin{array}{c}\text { Raised amylase } \\
\text { and lipase }\end{array}$ & $\begin{array}{c}\text { Raised lipase with } \\
\text { normal amylase levels }\end{array}$ & $\begin{array}{c}\text { Total raised lipase } \\
\text { levels }\end{array}$ \\
\hline & $41(82 \%)$ & $09(18 \%)$ & $50(100 \%)$ \\
\hline
\end{tabular}




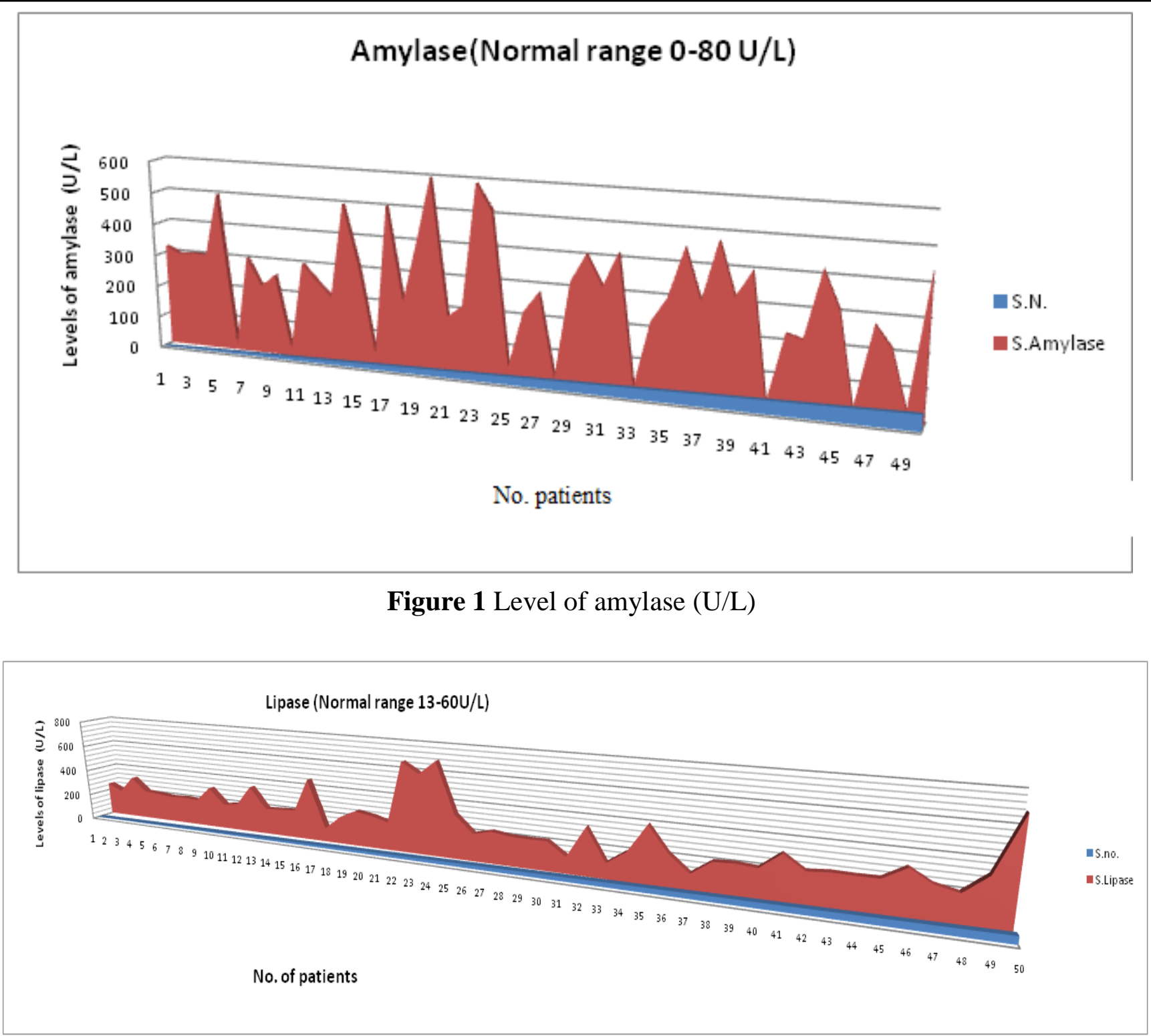

Figure 2 Level of serum lipase (U/L)

\section{Conclusion}

On the basis of the above result we can conclude that the level of serum lipase increases acute pancreatitis. All diseased patients were subjected for the serial estimation of serum lipase on daily basis. The final conclusion was that the level of serum lipase comes down to the normal level with full recovery of the patient from acute pancreatitis. According to British society Gastroenterology guideline for the management of acute pancreatitis, lipase is the main focus towards the diagnosis of acute pancreatitis ${ }^{(7)}$. Our studies goes in accordance to the previous studies ${ }^{(4,5)}$, which shows that serum lipase in case of acute pancreatitis is better diagnostic marker than serum amylase. In our study, $82 \%$ patient of acute pancreatitis had both amylase and lipase raised and $100 \%$ of acute pancreatitis patient had lipase raised, irrespective of etiology.

\section{Bibliography}

1. An elevated serum lipase or trypsin value is usually diagnostic of acute pancreatitis "these tests are specially helpful in patient with non $p$ pancreatitis cause of hyperamylesemia." Harrison $16^{\text {th }}$ edition page no. 1897.

2. Burtis C A, Ashwood ER, Bruns DE. Tietz textbook of clinical and molecular diagnostic. $6^{\text {th }}$ edition page $616-621$. 
3. Chang JWY, Chung $\mathrm{CH}$. Diagnosing Acute pancreatitis: Hong Kong J Emerg Med.2011;18:20-24 (Google scholar).

4. Apple F, Benson P, Preese L, Eastep S, Bilodeau L, Heiler G. Lipase and pancreatic amylase activities in tissues and in patients with hyperamylesemia. Am J Clin Pathol.1991;96:610-4.(Pub Med).

5. Agarwal N, Piitchumoni CS, Sivaprasad AV. Evaluating tests for acute pancreatitis. Am J Gastroenterol.1990; 85:356-366(Pub Med).

6. Yadav D, Agarwal N, Piitchumoni CS.A critical Evaluation of laboratory tests for acut pancreatitis. Am J Gastroenterol. 2002;97:1309-1318 (Pub Med).

7. UK working party on acute pancreatitis. UK guidelines for the management of acute pancreatitis. Gut 2005;54 (Suppl3) (Pub Med). 